\title{
Tax Rates Effects on the Risk Level of Listed Viet Nam Wholesale and Retail Firms during Global Economic Crisis 2007-2009
}

\author{
Dinh Tran Ngoc Huy*
}

\begin{abstract}
The emerging stock market in Viet Nam has been developed since 2006 and was affected by the financial crisis 2007-2009. This study analyzes the impacts of tax policy on market risk for the listed firms in the wholesale and retail industry as it becomes necessary. First, by using quantitative and analytical methods to estimate asset and equity beta of total 9 listed companies in Viet Nam wholesale and retail industry with a proper traditional model, we found out that the beta values, in general, for many institutions are acceptable. Second, under 3 different scenarios of changing tax rates $(20 \%, 25 \%$ and $28 \%)$, we recognized that there is not large disperse in equity beta values, estimated at $0,603,0,609$ and 0,613 . Third, by changing tax rates in 3 scenarios $(25 \%, 20 \%$ and $28 \%$ ), we recognized that both equity and asset beta mean values have positive relationship with the increasing levels of tax rate. Finally, this paper provides some outcomes that could provide companies and government more evidence in establishing their policies in governance.
\end{abstract}

Keywords : beta, capital structure, economic crisis, risk, tax rate, wholesale and retail industry http://dx.doi.org/10.4314/ejbe.v5i1.3

\footnotetext{
*MBA, PhD candidate, Banking University HCMC, Viet Nam - GSIM International University of Japan, Japan, dtnhuy2010@gmail.com
} 
Tax Rates Effects on the Risk Level of Wholesale and Retail Firms

\section{Introduction}

Together with the development of the whole economy and the growth of FDI, throughout many recent years, Viet Nam wholesale and retail industry is considered as one of the active economic sectors, which has some positive effects for the economy.

This paper is organized as follows. The research issues and literature review will be covered in the next sections ( 2 and 3 ), by way of a short summary. Then, methodology and conceptual theories are introduced in sections 4 and 5 . Section 6 describes the data in empirical analysis. Section 7 presents empirical results and findings. Next, section 8 covers the analytical results. Then, section 9 presents analysis of risk. Lastly, section 10 will conclude with some policy suggestions. This paper also supports readers with references, exhibits and relevant web sources.

\section{Research Issues}

We mention some issues on the estimating of impacts of tax rates on beta for listed wholesale and retail companies in Viet Nam stock exchange as follows:

Issue 1: Whether the risk level of wholesale and retail firms under the different changing scenarios of tax rates increase or decrease so much.

Issue 2: Whether the disperse distribution of beta values become large in the different changing scenarios of tax rates estimated in the wholesale and retail industry.

Besides, we also propose some hypotheses for the above issues:

Hypothesis 1: because tax may strongly affect business returns, changing tax scenarios could strongly affect firm risk.

Hypothesis 2: as tax policy is vital for the business development, there will be large disperse in beta or risk values estimated. 
Tax Rates Effects on the Risk Level of Wholesale and Retail Firms

\section{Literature review}

Smith (2004) mentions that in Chicago, properties located in a designated TIF (tax increment financing) district will exhibit higher rates of appreciation after the area is designated a qualifying TIF district when compared to those properties selling outside TIF districts, and when compared to properties that sell within TIF district boundaries prior to designation.

David (2009) stated that the U.S states can increase the likelihood of using tax rate adjustments to cope with fiscal volatility rather than (more harmful) spending fluctuations. Robert et all (2011) recognized a significant positive relation between changes in intercorporate investment and changes in corporate marginal tax rates on ordinary income.

George and Jot Yau (2012) found that there is a positive relationship between transaction cost and price volatility, suggesting that the imposition of a transaction tax could increase financial market fragility, increasing the likelihood of a financial crisis rather than reducing it. Mark (2012) found out in some European countries during the crisis raising tax rates and tax burdens, the trend in which overall revenue levels were broadly stable, while marginal rates in corporate and top personal income declined has stopped. Then, Filip (2012) believed that low levels of taxation, esp. low levels of taxation on the income or wealth of the so-called productive segments of society, are beneficial for economic growth.

Next, Ruud et al. (2013) said that greater tax bias is associated with significantly higher aggregate bank leverage, and this in turn is associated with a significantly greater chance of crisis.

Then, Sung, Mark and Laura (2013) also indicated that business property values are more responsive to changes in tax rates as compared to residential property.

EJBE Vol. 5 No. 1/2015 
Tax Rates Effects on the Risk Level of Wholesale and Retail Firms

Finally, tax rate can be considered as one among many factors that affect business risk of wholesale and retail firms.

\section{Conceptual theories}

\section{The impact of fiscal policy on the economy}

Tax policy is one among major fiscal policies. When the government decides to change the tax policy or tax rates, the mobility of capital in the markets will be affected.

In a specific industry such as wholesale and retail industry, on the one hand, using tax policy with a decrease or increase in tax rate could affect tax revenues, profit after tax and financial results and compensation and jobs of the industry. And it also shows the purpose of fiscal policy: following either contractionary or expansionary directions.

During and after financial crises such as the 2007-2009 crisis, there raises concerns about fiscal policies or public policies of many countries, in both developed and developing markets. The government might choose either lowering the tax rates or cutting the public expenditures while increasing demand stimulating programs to resolve difficulties from the crisis.

\section{Methodology}

In this study, we use the live data during the crisis period (2007-2011) from the stock exchange market in Viet Nam (HOSE and HNX) to estimate systemic risk results and tax impacts.

In this research, analytical, philosophical and tax rate scenario analysis methods are used. Analytical data is from the situation of listed wholesale and retail firms in $\mathrm{VN}$ stock exchange and current tax rate is $25 \%$. We select three 
Tax Rates Effects on the Risk Level of Wholesale and Retail Firms

(3) tax scenarios: $20 \%, 25 \%$ and $28 \%$ which can be considered as suitable tax scenarios in the current economic conditions.

Finally, we use the results to suggest policy for both these enterprises, relevant organizations and government.

\section{General Data Analysis}

The research sample has a total of 9 listed firms in the wholesale and retail market with the live data from the stock exchange. Firstly, we estimate equity beta values of these firms and use financial leverage to estimate asset beta values of them. Secondly, we change the tax rate from $25 \%$ to $28 \%$ and $20 \%$ to see the sensitivity of beta values. We found out that in 3 cases (rate $=20 \%$, $25 \%$, and $28 \%$ ), asset beta mean is estimated at $0,323,0,327$ and 0,328 which are negatively correlated with tax rate. Also in 3 scenarios, we found out var of asset beta estimated at 0,026 (almost the same) which shows acceptable risk dispersion. Tax rate changes almost have no effect on asset beta var under financial leverage.

\section{Empirical Research Findings and Discussion}

In the section below, data used are from a total of 9 listed wholesale and retail companies on VN stock exchange (HOSE and HNX mainly). In scenario 1, current tax rate is $25 \%$ which is used to calculate market risk (beta). Then, two (2) tax rate scenarios are changed up to $28 \%$ and down to $20 \%$, compared to the current corporate tax rate.

Market risk (beta) under the impact of tax rate, includes: 1) equity beta; and 2) asset beta.

EJBE Vol. 5 No. $1 / 2015$ 
Tax Rates Effects on the Risk Level of Wholesale and Retail Firms

\subsection{Scenario 1: current tax rate is $25 \%$}

In the case of tax rate of $25 \%$, all beta values of 9 listed firms on VN wholesale and retail market are as follows:

Table 1 - Market risk of listed companies on VN wholesale and retail market $(\mathrm{t}=25 \%)$

\begin{tabular}{|c|c|c|c|c|c|}
\hline $\begin{array}{c}\text { Order } \\
\text { No. }\end{array}$ & $\begin{array}{l}\text { Company } \\
\text { stock } \\
\text { code }\end{array}$ & $\begin{array}{l}\text { Equity } \\
\text { beta }\end{array}$ & $\begin{array}{c}\text { Asset beta } \\
\text { (assume debt } \\
\text { beta = 0) }\end{array}$ & Note & $\begin{array}{l}\text { Financial } \\
\text { leverage }\end{array}$ \\
\hline 1. & $\mathrm{HHS}$ & 0,818 & 0,538 & PIT as comparable & $34,2 \%$ \\
\hline 2 & IMT & 0,296 & 0,286 & TH1 as comparable & $3,4 \%$ \\
\hline 3 & TH1 & 0,501 & 0,196 & & $60,8 \%$ \\
\hline 4 & BSC & 0,395 & 0,330 & FBA as comparable & $18,7 \%$ \\
\hline 5 & PET & 1,170 & 0,322 & & $72,4 \%$ \\
\hline 6 & BTT & 0,722 & 0,561 & PIT as comparable & $22,8 \%$ \\
\hline 7 & CMV & 0,341 & 0,112 & PIT as comparable & $67,9 \%$ \\
\hline 8 & PIT & 0,881 & 0,447 & & $49,2 \%$ \\
\hline 9 & VT1 & 0,358 & 0,156 & BTT as comparable & $57,5 \%$ \\
\hline
\end{tabular}

\subsection{Scenario 2: tax rate increases up to $28 \%$}

If corporate tax rate increases up to $28 \%$, all beta values of a total of 9 listed firms on $\mathrm{VN}$ wholesale and retail market are as shown below:

Table 2 - Market risks of listed wholesale and retail firms $(\mathrm{t}=28 \%)$

\begin{tabular}{|c|l|c|c|l|r|}
\hline $\begin{array}{c}\text { Order } \\
\text { No. }\end{array}$ & $\begin{array}{c}\text { Company } \\
\text { stock code }\end{array}$ & $\begin{array}{c}\text { Equity } \\
\text { beta }\end{array}$ & $\begin{array}{c}\text { Asset beta } \\
\text { (assume debt } \\
\text { beta = 0) }\end{array}$ & Note & $\begin{array}{r}\text { Financial } \\
\text { leverage }\end{array}$ \\
\hline 1 & HHS & 0,818 & 0,538 & PIT as comparable & $34,2 \%$ \\
\hline 2 & IMT & 0,297 & 0,287 & TH1 as comparable & $3,4 \%$ \\
\hline 3 & TH1 & 0,512 & 0,201 & & $60,8 \%$ \\
\hline 4 & BSC & 0,397 & 0,323 & FBA as comparable & $18,7 \%$ \\
\hline 5 & PET & 1,170 & 0,322 & & $72,4 \%$ \\
\hline 6 & BTT & 0,727 & 0,561 & PIT as comparable & $22,8 \%$ \\
\hline 7 & CMV & 0,349 & 0,112 & PIT as comparable & $67,9 \%$ \\
\hline 8 & PIT & 0,881 & 0,447 & & $49,2 \%$ \\
\hline 9 & VT1 & 0,368 & 0,156 & BTT as comparable & $57,5 \%$ \\
\hline
\end{tabular}

EJBE Vol. 5 No. 1/2015 
Tax Rates Effects on the Risk Level of Wholesale and Retail Firms

\subsection{Scenario 3: tax rate decreases down to $20 \%$}

If corporate tax rate decreases down to $20 \%$, all beta values of a total of 9 listed firms on the wholesale and retail market in $\mathrm{VN}$ are as follows:

Table 3 - Market risk of listed wholesale and retail firms $(\mathrm{t}=20 \%)$

\begin{tabular}{|c|l|c|c|c|r|}
\hline $\begin{array}{c}\text { Order } \\
\text { No. }\end{array}$ & $\begin{array}{c}\text { Compan } \\
\text { y stock } \\
\text { code }\end{array}$ & $\begin{array}{c}\text { Equity } \\
\text { beta }\end{array}$ & $\begin{array}{c}\text { Asset beta } \\
\text { (assume debt } \\
\text { beta = 0) }\end{array}$ & Note & $\begin{array}{c}\text { Financia } \\
\text { I } \\
\text { leverage }\end{array}$ \\
\hline 1 & HHS & 0,818 & 0,538 & PIT as comparable & $34,2 \%$ \\
\hline 2 & IMT & 0,296 & 0,286 & TH1 as comparable & $3,4 \%$ \\
\hline 3 & TH1 & 0,484 & 0,190 & & $60,8 \%$ \\
\hline 4 & BSC & 0,391 & 0,318 & FBA as comparable & $18,7 \%$ \\
\hline 5 & PET & 1,170 & 0,322 & & $72,4 \%$ \\
\hline 6 & BTT & 0,713 & 0,551 & PIT as comparable & $22,8 \%$ \\
\hline 7 & CMV & 0,328 & 0,105 & PIT as comparable & $67,9 \%$ \\
\hline 8 & PIT & 0,881 & 0,447 & & $49,2 \%$ \\
\hline 9 & VT1 & 0,342 & 0,145 & BTT as comparable & $57,5 \%$ \\
\hline
\end{tabular}

All the data in the three tables above show that values of equity and asset beta in the case of increasing tax rate up to $28 \%$ or decreasing rate down to $20 \%$ have small fluctuation.

\section{Comparing statistical results in 3 scenarios of changing tax rate:}

Table 4 - Statistical results $($ tax rate $=25 \%)$

\begin{tabular}{|l|c|c|c|}
\hline Statistic results & Equity beta & $\begin{array}{c}\text { Asset beta (assume } \\
\text { debt beta = 0) }\end{array}$ & Difference \\
\hline MAX & 1,170 & 0,561 & 0,6083 \\
\hline MIN & 0,296 & 0,112 & 0,1841 \\
\hline MEAN & 0,609 & 0,328 & 0,2812 \\
\hline VAR & 0,0919 & 0,0260 & 0,0659 \\
\hline \multicolumn{3}{|r|}{ Note: Sample size $: 9$} \\
\hline
\end{tabular}

EJBE Vol. 5 No. 1/2015 
Tax Rates Effects on the Risk Level of Wholesale and Retail Firms

Table 5 - Statistical results $($ tax rate $=28 \%)$

\begin{tabular}{|l|c|c|c|}
\hline Statistic results & Equity beta & $\begin{array}{c}\text { Asset beta (assume } \\
\text { debt beta = 0) }\end{array}$ & Difference \\
\hline MAX & 1,170 & 0,561 & 0,6083 \\
\hline MIN & 0,297 & 0,112 & 0,1844 \\
\hline MEAN & 0,613 & 0,328 & 0,2857 \\
\hline VAR & 0,0904 & 0,0259 & 0,0645 \\
\hline \multicolumn{3}{|r|}{ Note: Sample size : 9} \\
\hline
\end{tabular}

Table 6- Statistical results (tax rate $=20 \%$ )

\begin{tabular}{|l|c|c|c|}
\hline Statistic results & Equity beta & $\begin{array}{c}\text { Asset beta (assume } \\
\text { debt beta = 0) }\end{array}$ & Difference \\
\hline MAX & 1,170 & 0,551 & 0,6191 \\
\hline MIN & 0,296 & 0,105 & 0,1907 \\
\hline MEAN & 0,603 & 0,323 & 0,2800 \\
\hline VAR & 0,0943 & 0,0265 & 0,0678 \\
\hline
\end{tabular}

Based on the above results, we find out:

Equity beta mean values in all 3 scenarios are low $(<0,7)$ and asset beta mean values are also small $(<0,4)$ although max equity beta values in some cases might be higher than (>) 1 . In the case of current tax rate of $25 \%$, equity beta value fluctuates in an acceptable range from 0,296 ( $\min )$ up to 1,17 (max) and asset beta fluctuates from $0,112(\min )$ up to $0,561(\max )$. If corporate tax rate increases to $28 \%$, equity beta changes from 0,297 to 1,17 and asset beta move in an unchanged range. When tax rate decreases down to $20 \%$, equity beta value also fluctuates in an unchanged range whereas asset beta changes from 0,105 to 0,551 (showing a decrease in asset beta min).

Besides, Exhibit 6 informs us that in the case of $28 \%$ tax rate, average equity beta value of 9 listed firms increases down to 0,004 while average asset beta value of these 9 firms increases more up to 0,214 . Then, when tax rate reduces 
Tax Rates Effects on the Risk Level of Wholesale and Retail Firms

to $20 \%$, average equity beta value of 9 listed firms goes down to $-0,007$ and average asset beta value of 9 firms up to 0,209 .

Chart 1 below shows us : when tax rate decreases down to $20 \%$, average equity and asset beta values increase slightly $(0,603$ and 0,323$)$ compared to those at the initial rate of $25 \%(0,609$ and 0,327$)$, which shows opposite movement compared to the market index. At the same time, when tax rate increases up to $28 \%$, average equity beta decreases slightly whereas average asset beta value remains unchanged (to 0,613 and 0,328 ). However, the fluctuation of equity beta value $(0,094)$ in the case of $20 \%$ tax rate is higher than $(>)$ the results in the rest 2 tax rate cases.

Chart 1 - Comparing statistical results of three (3) scenarios of changing tax rate (2007-2009)

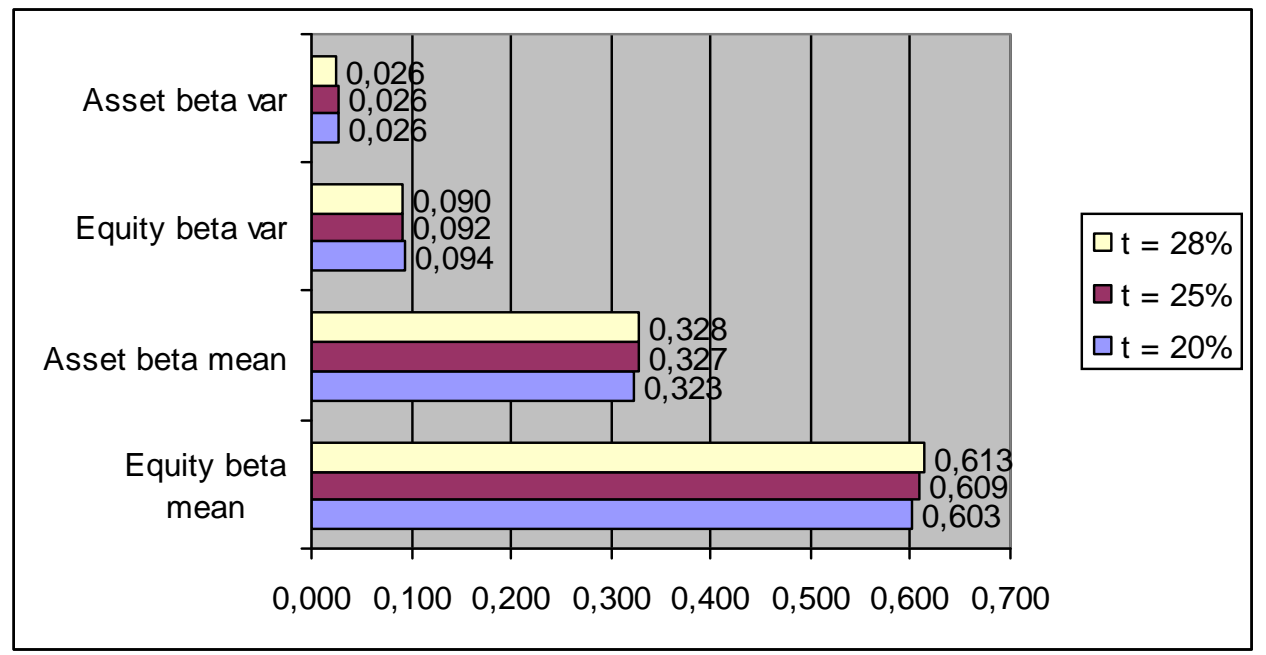

EJBE Vol. 5 No. 1/2015 
Tax Rates Effects on the Risk Level of Wholesale and Retail Firms

Chart 2 - Comparing statistical results of three (3) scenarios of changing tax rate $(2007-2011)$

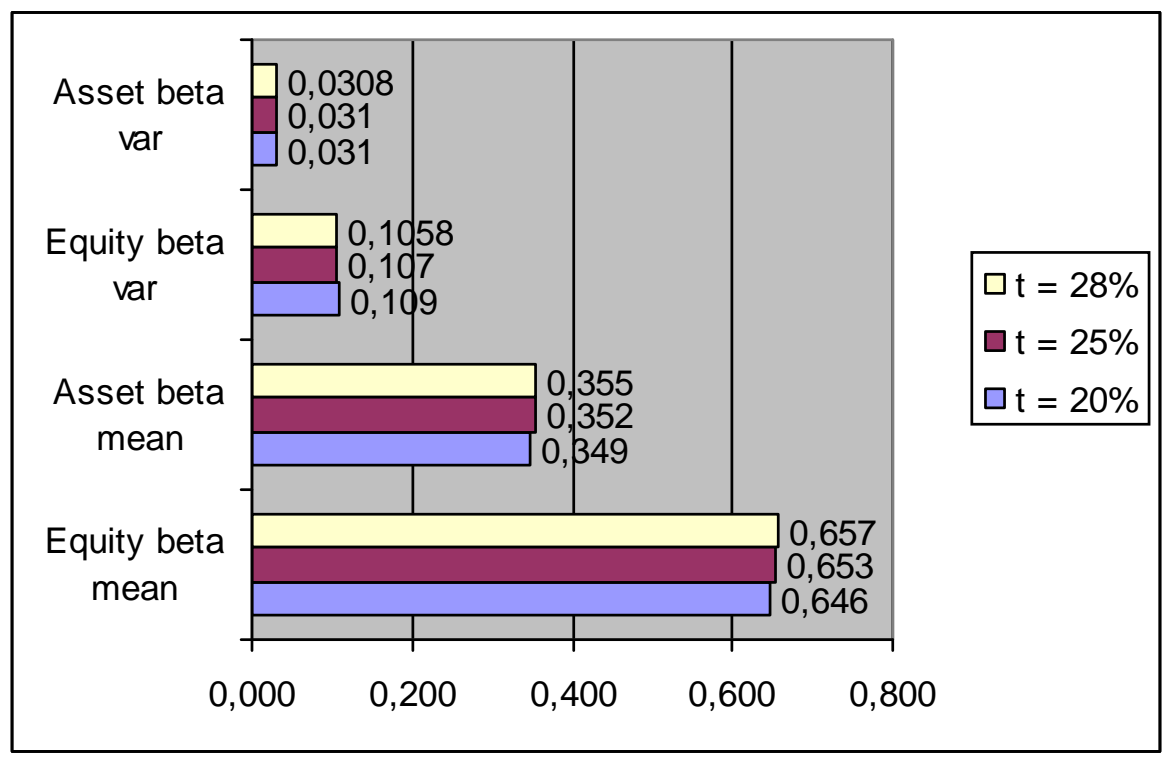

\section{Risk analysis}

On the one hand, in the case of decreasing tax rate, (20\%), the market and companies can receive more benefits such as generating more jobs, output and compensation, but the government budget can have deficit and the government has to cut expenditures. Hence, changes in tax rates can have both positive and negative impacts on the local market.

On the other hand, in the case of increasing tax rate $(28 \%)$, the government will have budget to finance public expenditures but the income tax burden could reduce both demand and supply, as well as the output, jobs and compensation.

Our calculations give the results of two betas: equity and asset beta which can be used in the CAPM model and in WACC formula to estimate cost of equity and cost of capital. 
Tax Rates Effects on the Risk Level of Wholesale and Retail Firms

\section{Conclusion and Policy suggestion}

In summary, the government has to consider the impacts on the mobility of capital in the markets when it changes the tax policy or tax rates. Besides, it continues to increase the effectiveness of building the legal system and regulation and macro policies supporting the plan of developing wholesale and retail market. The Ministry of Finance Continues to increase the effectiveness of fiscal policies and tax policies which are needed to combine with other macro policies at the same time, although we could note that in this study when tax rate is going to increase up to $28 \%$, the risk level does not increase so much, compared to the case it is going to decrease down to $20 \%$. And the risk dispersion during 2007-2009 (asset beta var of 0,026) is smaller than that during 2007-2011 (0,031) in the case of $25 \%$ tax.

The State Bank of Viet Nam continues to increase the effectiveness of capital providing channels for wholesale and retail companies. Furthermore, the entire efforts among many different government bodies need to be coordinated.

Finally, this paper suggests implications for further research and policy suggestion for the Viet Nam government and relevant organizations, economists and investors from current market conditions. For example, we recognize that the government can increase public expenditure if tax rate increases up to $28 \%$, otherwise it has to borrow to finance government expenses.

EJBE Vol. 5 No. 1/2015 
Tax Rates Effects on the Risk Level of Wholesale and Retail Firms

\section{References}

ADB and Viet Nam Fact Sheet, 2010.

Ameer, Beenish., and Jamil, Moazzam., (2013), A Test of Fama and French

Three Factor Model in Pakistan Equity Market, Global Journal of

Management and Business Research, Vol.13, Issue 7, pp. 24-28.

Baker, Kent H., Singleton, Clay J., and Veit, Theodore E., (2011), Survey

Research in Corporate Finance: Bridging The Gap Between Theory and

Practice, Oxford University Press.

Flifel, Kaouther., (2012), Financial Markets between Efficiency and

Persistence : Empirical Evidence on Daily Data, Asian Journal of

Finance and Accounting.

Huy, Dinh T.N., (2013), Estimating Beta of Viet Nam Listed Public Utilities,

Natural Gas and Oil Company Groups During and After The Financial

Crisis 2007-2011, Economic and Business Review, Vol. 15, No. 1, pp.

57-71.

Huy, Dinh T.N., (2013), Beta of Viet Nam Listed Computer and Electrical

Company Groups During and After The Financial Crisis 2007-2011,

Asian Journal of Finance \& Accounting, Vol. 5, No. 1, pp. 127-139.

Mamun, Md. Abdullah Al, (2013), Performance Evaluation of Prime Bank

Limited in Terms of Capital Adequacy, Global Journal of Management

and Business Research, Vol. 13, Issue 9, pp. 26-29.

Ovat, Okey O., (2013), Liquidity Constraints and Entrepreneurial Financing in

Nigeria: The Fate of Fresh Graduate Entrepreneurs, Global Journal of

Management and Business Research, Vol.13, Issue 9, pp. 49-57.

Raj, Bhavana., and Sindhu., (2013), Skill Level in Risk Management: Training

in Credit Risk - A Comparative Study of Indian Banks and Foreign

Banks, Global Journal of Management and Business Research, Vol.13,

Issue 7, pp. 56-62.

Rehman, Syed S.S.U., (2013), Relationship Between Financial Leverage and

Financial Performance: Empirical Evidence of Listed Sugar Companies

of Pakistan, Global Journal of Management and Business Research,

Vol.13, Issue 8, pp. 45-53.

EJBE Vol. 5 No. 1/2015 
Tax Rates Effects on the Risk Level of Wholesale and Retail Firms

\section{Web links}

http://www.ifc.org/ifcext/mekongpsdf.nsf/Content/PSDP22

http://www.mofa.gov.vn/vi/

http://www.hsx.vn/hsx/

www.tuoitre.com.vn

www.saigontimes.com.vn

www.mof.gov.vn

www.vneconomy.com.vn

www.sbv.gov.vn 
Tax Rates Effects on the Risk Level of Wholesale and Retail Firms

\section{Exhibit}

Exhibit 1 - Interest rates in banking industry during crisis (source: Viet Nam commercial banks)

\begin{tabular}{|c|c|c|c|}
\hline Year & $\begin{array}{l}\text { Borrowing } \\
\text { Interest rates }\end{array}$ & $\begin{array}{l}\text { Deposit } \\
\text { Rates }\end{array}$ & Note \\
\hline 2011 & $18 \%-22 \%$ & $13 \%-14 \%$ & \\
\hline 2010 & $19 \%-20 \%$ & $13 \%-14 \%$ & Approximately \\
\hline 2009 & $9 \%-12 \%$ & $9 \%-10 \%$ & (2007: required reserves ratio at \\
\hline 2008 & $19 \%-21 \%$ & $15 \%-16,5 \%$ & $\begin{array}{l}\text { SBV is changed from } 5 \% \text { to } \\
10 \% \text { ) }\end{array}$ \\
\hline 2007 & $12 \%-15 \%$ & $9 \%-11 \%$ & $\begin{array}{l}\text { (2009: special supporting } \\
\text { interest rate is } 4 \%)\end{array}$ \\
\hline
\end{tabular}

Exhibit 2 - Basic interest rate changes in Viet Nam (source: State Bank of Viet Nam and Viet Nam economy)

$\begin{array}{lll}\text { Year } & \text { Basic rate } & \text { Note } \\ 2011 & 9 \% & \\ 2010 & 8 \% & \\ 2009 & 7 \% & \\ 2008 & 8,75 \%-14 \% & \begin{array}{l}\text { Approximately, } \\ \text { fluctuated }\end{array} \\ & & \\ 2007 & 8,25 \% & \\ 2006 & 8,25 \% & \\ 2005 & 7,8 \% & \\ 2003 & 7,5 \% & \\ 2002 & 7,5 \% & \\ 2001 & 7,44 \% & \text { Approximately, } \\ & 7,2 \%-8,7 \% & \text { fluctuated } \\ 2000 & 9 \% & \end{array}$

Exhibit 3 - Inflation, GDP growth and macroeconomic factors (source: Viet Nam commercial banks and economic statistical bureau)

$\begin{array}{llll}\text { Year } & \text { Inflation } & \text { GDP } & \text { USD/VND rate } \\ 2011 & 18 \% & 5,89 \% & 20.670 \\ 2010 & 11,75 \% & 6,5 \% & 19.495 \\ & \begin{array}{l}\text { (Estimated at } \\ \text { Dec 2010) }\end{array} & \text { (expected) } & \\ 2009 & 6,88 \% & 5,2 \% & 17.000 \\ 2008 & 22 \% & 6,23 \% & 17.700 \\ 2007 & 12,63 \% & 8,44 \% & 16.132\end{array}$


Tax Rates Effects on the Risk Level of Wholesale and Retail Firms

$\begin{array}{lll}2006 & 6,6 \% & 8,17 \% \\ 2005 & 8,4 \% & \\ \text { Note } & & \text { approximately }\end{array}$

Exhibit 4: GDP growth Vi t Nam 2006-2010 (source: Bureau Statistic)

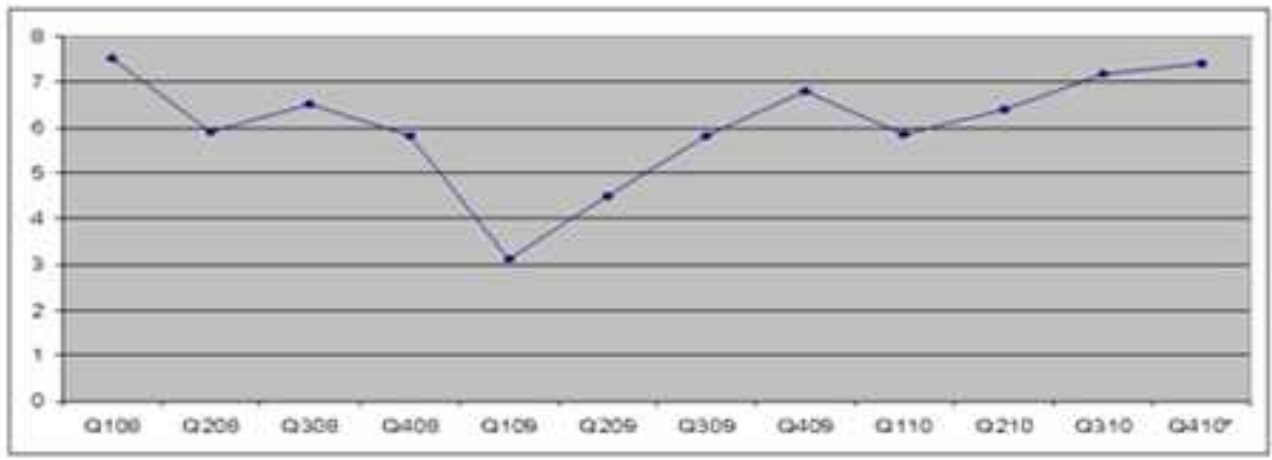

Exhibit 5: Risk and financial leverage of 9 listed banking firms on VN stock exchange period 2007-2011

\begin{tabular}{|c|c|c|c|c|}
\hline $\begin{array}{l}\text { Order } \\
\text { No. }\end{array}$ & $\begin{array}{l}\text { Company } \\
\text { stock } \\
\text { code }\end{array}$ & Equity beta & $\begin{array}{l}\text { Asset beta (assume } \\
\text { debt beta }=0 \text { ) }\end{array}$ & $\begin{array}{l}\text { Financial } \\
\text { leverage }\end{array}$ \\
\hline 1 & ACB & 0,7874 & 0,0378 & $95,2 \%$ \\
\hline 2 & CTG & 0,5540 & 0,0312 & $94,4 \%$ \\
\hline 3 & EIB & 0,3847 & 0,0365 & $90,5 \%$ \\
\hline 4 & HBB & 0,1335 & 0,0138 & $89,7 \%$ \\
\hline 5 & MBB & 0,0722 & 0,0054 & $92,5 \%$ \\
\hline 6 & NVB & 0,0211 & 0,0026 & $87,7 \%$ \\
\hline 7 & SHB & 1,0038 & 0,0824 & $91,8 \%$ \\
\hline 8 & STB & 0,7395 & 0,0721 & $90,3 \%$ \\
\hline 9 & VCB & 0,4083 & 0,0299 & $92,7 \%$ \\
\hline
\end{tabular}


Tax Rates Effects on the Risk Level of Wholesale and Retail Firms

Exhibit 6 - Increase/decrease risk level of listed wholesale and retail firms under changing scenarios of tax rates : 25\%, 28\%, 20\% (period 2007 -2009)

\begin{tabular}{|c|c|c|c|c|c|c|c|}
\hline \multirow[b]{2}{*}{$\begin{array}{l}\text { Orde } \\
\text { r No. }\end{array}$} & \multirow[b]{2}{*}{$\begin{array}{c}\text { Compan } \\
\text { y stock } \\
\text { code }\end{array}$} & \multicolumn{2}{|c|}{$t=25 \%$} & \multicolumn{2}{|c|}{$t=28 \%$} & \multicolumn{2}{|c|}{$t=20 \%$} \\
\hline & & $\begin{array}{c}\text { Equity } \\
\text { beta }\end{array}$ & $\begin{array}{c}\text { Asset } \\
\text { beta }\end{array}$ & $\begin{array}{l}\text { Increase } \\
\text { /Decreas } \\
\text { e (equity } \\
\text { beta) }\end{array}$ & $\begin{array}{l}\text { Increase } \\
\text { /Decreas } \\
\text { e (asset } \\
\text { beta) }\end{array}$ & $\begin{array}{l}\text { Increase } \\
\text { /Decreas } \\
\text { e (equity } \\
\text { beta) }\end{array}$ & $\begin{array}{l}\text { Increase } \\
\text { /Decreas } \\
\text { e (asset } \\
\text { beta) }\end{array}$ \\
\hline 1 & $\mathrm{HHS}$ & 0,818 & 0,538 & 0,000 & 0,000 & 0,000 & 0,000 \\
\hline 2 & IMT & 0,296 & 0,286 & 0,000 & 0,000 & $-0,001$ & 0,000 \\
\hline 3 & TH1 & 0,501 & 0,196 & 0,011 & 0,004 & $-0,017$ & $-0,007$ \\
\hline 4 & $\mathrm{BSC}$ & 0,395 & 0,000 & 0,002 & 0,323 & $-0,004$ & 0,318 \\
\hline 5 & PET & 1,170 & 0,000 & 0,000 & 0,322 & 0,000 & 0,322 \\
\hline 6 & BTT & 0,722 & 0,000 & 0,005 & 0,561 & $-0,009$ & 0,551 \\
\hline 7 & CMV & 0,341 & 0,000 & 0,009 & 0,112 & $-0,013$ & 0,105 \\
\hline 8 & PIT & 0,881 & 0,000 & 0,000 & 0,447 & 0,000 & 0,447 \\
\hline 9 & VT1 & 0,358 & 0,000 & 0,010 & 0,156 & $-0,016$ & 0,145 \\
\hline & & \multicolumn{2}{|c|}{ Average } & 0,004 & 0,214 & $-0,007$ & 0,209 \\
\hline
\end{tabular}

Exhibit 7- VNI Index and other stock market index during crisis (2006-2010)

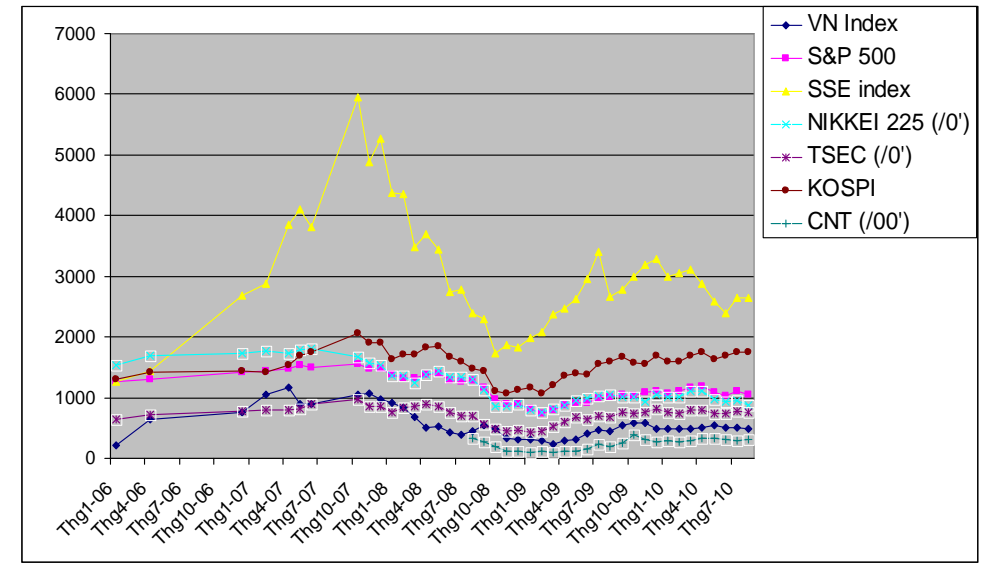

Author note: My sincere thanks go to the editorial office and Lecturers/Doctors at Banking University and International University of Japan. Through the qualitative analysis, please kindly email me if any error is found. 